\title{
Role of district poverty initiatives project (DPIP) for the enhancement of livelihood of the villagers of Chhatarpur district of M.P.
}

\section{D.P. RAI, SANTOSH KUMAR SINGH AND SACHINDRA KUMAR PANDEY}

Received : 15.12.2016; Revised : 01.03.2017; Accepted : 15.03.2017

\begin{abstract}
Study was conducted in Bhopal district of M.P. in 2011. Unemployment and poverty in general is the non-availability of a remunerative work to people who are otherwise worthy of doing such work with requisite efficiency. Government has formulated innumerable schemes and projects, which are in an operation to check growing poverty as a multi-prolonging strategy. The government of India has been launching several schemes for the unemployed in the rural and urban area of the country. The present study is helpful to administrators, policy makers, researchers and banking/financing institutions for making future strategies and also explores the weakness of the present implementations. An overwhelming majority of the poor are in rural areas and continue to depend on agriculture for want of any other livelihood opportunities outside the sector. About 52 per cent of the country's workforce and over 60 per cent of the population depends on agriculture which now accounts for just 17 per cent of the country's GDP, thus, perpetuating rural poverty and widening the rural-urban divide. Economic motivation is the degree to which an individual intends to earn to the maximum extent. Economic motivation has been conceptualized as one's orientation towards profit maximization in farming.
\end{abstract}

KEY WORDS : Role of DPIP, Constraints, Suggestions

How to cite this paper : Rai, D.P., Singh, Santosh Kumar and Pandey, Sachindra Kumar (2017). Role of district poverty initiatives project (DPIP) for the enhancement of livelihood of the villagers of Chhatarpur district of M.P. Internat. J. Com. \& Bus. Manage, 10(1) : 1-7, DOI: 10.15740/HAS/IJCBM/10.1/1-7.

\section{MEMBERS OF THE RESEARCH FORUM}

Correspondence to:

SANTOSH KUMAR SINGH, Department of Marketing, Faculty of Rural Development and Business Management, Mahatma Gandhi Chitrakoot Gramodaya Vishwavidyalaya, Chitrakoot, SATNA (M.P.) INDIA Email: santoshseco@gmail.com

Authors' affiliations:

D.P. RAI, Department of Technology Transfer, Faculty of Agriculture, Mahatma Gandhi Chitrakoot Gramodaya Vishwavidyalaya, Chitrakoot, SATNA (M.P.) INDIA

SACHINDRA KUMAR PANDEY, Krishi Vigyan Kendra, RATLAM (M.P.) INDIA 